\title{
Excretion Products of Shigella dysenteriae and Apoptotic Cell Death on Chick Embryo Muscle Tissue
}

\author{
Producto de Excreción de Shigella dysenteriae y la Muerte Celular \\ por Apoptosis en Tejido Muscular de Embrión de Pollo
}

"Marco Álvarez; **'Gidalia Urbina; "Claudia Müller \& *Lourdes Perdomo

\begin{abstract}
ALVÁREZ, M., URBINA, G.; MÜLLER, C. \& PERDOMO. L. Excretion products of Shigella dysenteriae and apoptotic cell death on chick embryo muscle tissue. Int. J. Morphol., 25(3):615-620, 2007.

SUMMARY: The aim of this study was to evaluate the acute cell injury of excretion products present in culture filtrate from Shigella dysenteriae in both whole lower limb of chick embryo ex vivo and myoblasts cells developed in hanging-drop cultures in vitro. Three controls were defined: a) Tyrode's solution b) brain-heart broth infusion (CCC) and c) supernatant not toxigenic of E.coli O157:H7. Shigella dysenteriae were culture for 24 hours and the excretion products were obtained after centrifugation of the culture. After $1 \mathrm{~h}$ of treatment, the morphologic changes in limbs treated with raw filtrate were evaluated through histopathological examination of sections stained with hematoxylin-eosin (H\&E-stain) and Gomori's trichrome by image analysis techniques. Quantification of apoptotic cells was measured by an enzyme-linked immunoassay TUNEL. The morphological feature of apoptosis were evaluated in culture myoblasts. In contrast with controls, the longitudinal section on treated thigh of chick embryo limb-buds show atrophy muscle tissue, detachment of few fibers, 57,14\% decrease in the number of cells, and loss of collagen substrate. Apoptotic index percent increase and mitotic index decrease in response to excretion products were observed, but were not significant. Membrane blebbing, vacuolation, small aggregates of chromatin around the nucleus and loss of cell adhesion were observed. Culture filtrate from Shigella dysenteriae produced cytotoxic effect on cell of muscle fibers with acute cell injuries suspected to be related to the apoptotic cell death.
\end{abstract}

KEY WORDS: Shigella dysenteriae; Shiga toxin; Chick embryo; Muscle tissue; Apoptosis.

\section{INTRODUCTION}

Shigella dysenteriae, just like many other bacteria, excrete toxins such as Shiga toxins (Stx's), which cause serious complications during infection (Paton \& Paton, 1998). Secreted bacterial proteins present in the culture filtrate of $S$. dysenteriae have been defined as exotoxins which cause cell death, mediate cell shape changes and disrupt normal cellular function. Depending on the type of cells infected, these toxins may cause necrotic or apoptotic cell death, alter cell signaling pathways without causing cell death, or induce the expression of pro- or anti-inflammatory cytokines which in turn exacerbate local inflammation or the development of systemic disease (Schmitt \& Meysick, 1999). S. dysenteriae has been defined as an enteric pathogenic agent that causes histologic changes of the intestinal mucosa following the shigella enterotoxin exposure. S. dysenteriae is ingested orally, often through contaminated food or water. $S$. dysenteriae first colonizes and then invades the epithelium, resulting in necrosis of the mucosa (O’Loughlin \& Robins-Browneb, 2001) Shigella and its secreted toxin induce severe inflammation in the ileocolonic regions of the gastrointestinal tract. Histological examination of intestinal epithelial cells infected with $S$. dysenteriae shows the presence of microvascular thrombosis and hemorrhagic lesions. Although the gastrointestinal tract is the organ most commonly affected during infection, it is not yet clear whether other structures are also target of Stx's and whether the apoptosis process is a response to cell's injuries. Some culture cells lines are highly sensitive to raw Shiga toxin. It becomes clear that a number of cell types in the body can be targeted by toxin-induced inhibition of protein synthesis and apoptosis (Meyers \& Kaplan, 2000). Numerous recent studies have shown Stx's trigger programmed cell

\footnotetext{
*Instituto Anatómico “José Izquierdo”, Facultad de Medicina, Universidad Central de Venezuela. http://www.med.ucv.ve/IA/SecMecElec.htm. **átedra de Microbiología, Escuela de Bioanálisis, Facultad de Medicina, Universidad Central de Venezuela. cidurb@yahoo.com.mex This work was supported by the CDCH. Project No. PG 09-30-5409-2004.
} 
death signaling cascades in intoxicated cells. The mechanisms of apoptosis induced by these toxins are emerging recently, and the data published to date suggest that the toxin may signal apoptosis in different cells types via different mechanisms (Cherla et al., 2003). From what was described above, it is possible to deduce that Shiga toxin may also affect other organs and that apoptotic signs could be considered as toxic cell injuries. The aim of this study was to evaluate the acute cell injury of excretion products present in culture filtrate from Shigella dysenteriae in both whole lower limb of chick embryo ex vivo and hanging-drop cultures in vitro. The chick embryo has a long and distinguished history as one of the best experimental models (Sterm, 2005), and has been used in various fields of research: physiology, biochemistry and toxicology, among others. On the other hand, hanging-drop culture techniques represent a good alternative of in vitro systems (Hartung et al., 2002).

\section{MATERIAL AND METHOD}

Culture filtrate of Shigella dysenteriae. Shigella dysenteriae strains were cultured on blood agar and grown anaerobically at $37^{\circ} \mathrm{C}$, for 24 hours. The strains were identified as serotype 1 by assay in monovalent antiserum A1 (FUVESIN). The colonies grown up to a density of $1 \times 10^{8}$ cells $/ \mathrm{ml}(0.5 \mathrm{Mc}$ Farland), were selected, resuspended in brain-heart infusion broth (BIH-Difco), and incubated at $37^{\circ} \mathrm{C}$ for 48 hours. Next, the culture was centrifuged at $4000 \mathrm{~g}$, for $30 \mathrm{~min}$, at $4^{\circ} \mathrm{C}$ thus obtaining the supernatants, which in turn were filtered through a $0.22 \mu \mathrm{m}$ Millex filter (Millipore, Bedford, MA) and excretion product was obtaining.

Ex vivo. Chick embryo thigh. Fertilized Rhode Island Red $\mathrm{X}$ eggs were incubated at $38{ }^{\circ} \mathrm{C}$, at $65 \%$ relative humidity, approximately. The Hamilton-Hamburger stage of the embryos at 8 days was determined (Hamburger \& Hamilton, 1992) The thighs were dissected and transferred to tubes containing 1.5 $\mathrm{ml}$ of $100 \%$ culture filtrate. Three control groups of chick thighs were defined: a) in Tyrode's solution, b) in brain-heart infusion broth (BIH-Difco) and c) in supernatants of E. coli 0157:h7 of nontoxigenic bacterial strains. All groups were incubated at $37^{\circ} \mathrm{C}$, for 1 hour.

Histopathological Examination. The controls and treated thighs were fixed by immersion in $10 \%$ formalin-zinc overnight and were embedded in Paraplast $®$. Serial longitudinal tissue sections of $5 \mu \mathrm{m}$ were stained with hematoxylin-eosin (H\&E-stain) and Gomori's trichrome. The samples were examined under a light microscope and captured by a video camera attached to it. The images were analyzed by image processing software (Image $\mathrm{J}$ ).
Determination of muscle tissue apoptosis. TdT method which labels the end of the broken strands of DNA, was used for in situ detection of apoptosis in tissue samples immobilized on slide. Tissue blocks were sectioned and mounted on polyL-Lysine slides. The slides obtained were processed through a terminal deoxynucleotidyl transferase-mediated dUTP nick end labeling (TUNEL) assay to detect fragmented nuclei in muscle tissue. An ApopTag® in situ detection kit was used according to the manufacturer's instructions. Briefly, the slides were pretreated with $\mathrm{H}_{2} \mathrm{O}_{2}$ and incubated with the reaction mixture containing terminal deoxynucleotidyl transferase and digoxigenin-conjugated dUTP, for $1 \mathrm{~h}$, at $37^{\circ} \mathrm{C}$. Labeled DNA was visualized with TACS Blue Label ${ }^{\mathrm{TM}}$. The positive control consisted in samples treated with TACS-nuclease control used to generate DNA breaks in the majority of the cells. For negative control, TdT was routinely omitted from the reaction mixture. The morphologic changes were evaluated by the apoptotic index; percentage of apoptotic nuclei per total nuclei. Mitotic index was determined by counting mitoses in strained muscle and muscle cells culture.

In vitro. Myogenesis. Explants from muscle tissue from thighs of 8-day-old chick embryos were used throughout the study. These were cultured on glass coverslips employing the hanging-drop technique. The explants were grown in a medium formed by total chick plasma and chick embryo extract diluted 1 to 8 in Tyrode's solution. The myoblasts cells developed for 24 hours at $38^{\circ} \mathrm{C}$ and were incubated with culture filtrate. Three control myoblasts groups were defined following the same pattern used for the chick embryo thighs. On the other hand, control and treated muscle cells grown in hanging-drop were fixed by immersion in $10 \%$ formalin-zinc for 1 hour then stained with toluidine blue and mounted.

Statistical Analysis. Data are expressed as mean \pm SD. A Student's t-test was used for the determination of the significance of differences. Differences between control and treated groups were considered significant at $p<0.05$. Actual sample's dimensions were obtained by morphometrical methods (Rojo et al., 2005)

\section{RESULTS}

\section{Ex vivo. Histopathological changes.}

Longitudinal section on thigh control (Figs. 1a, 1b), between proximodistal (pd) and dorsoventral (dv) axes of chick embryo limb-buds, showed muscle tissue $(\mathrm{m})$ region and cartilaginous primordium constituted by hyaline cartilage (h). High magnification pointed out hyaline and muscle tissue relationship, both structures connected were through collagen (Co) substrate (arrows). The muscle tissue (m) present skeletal muscle fibers with compact aspect and multinucleate cells (Fig. 

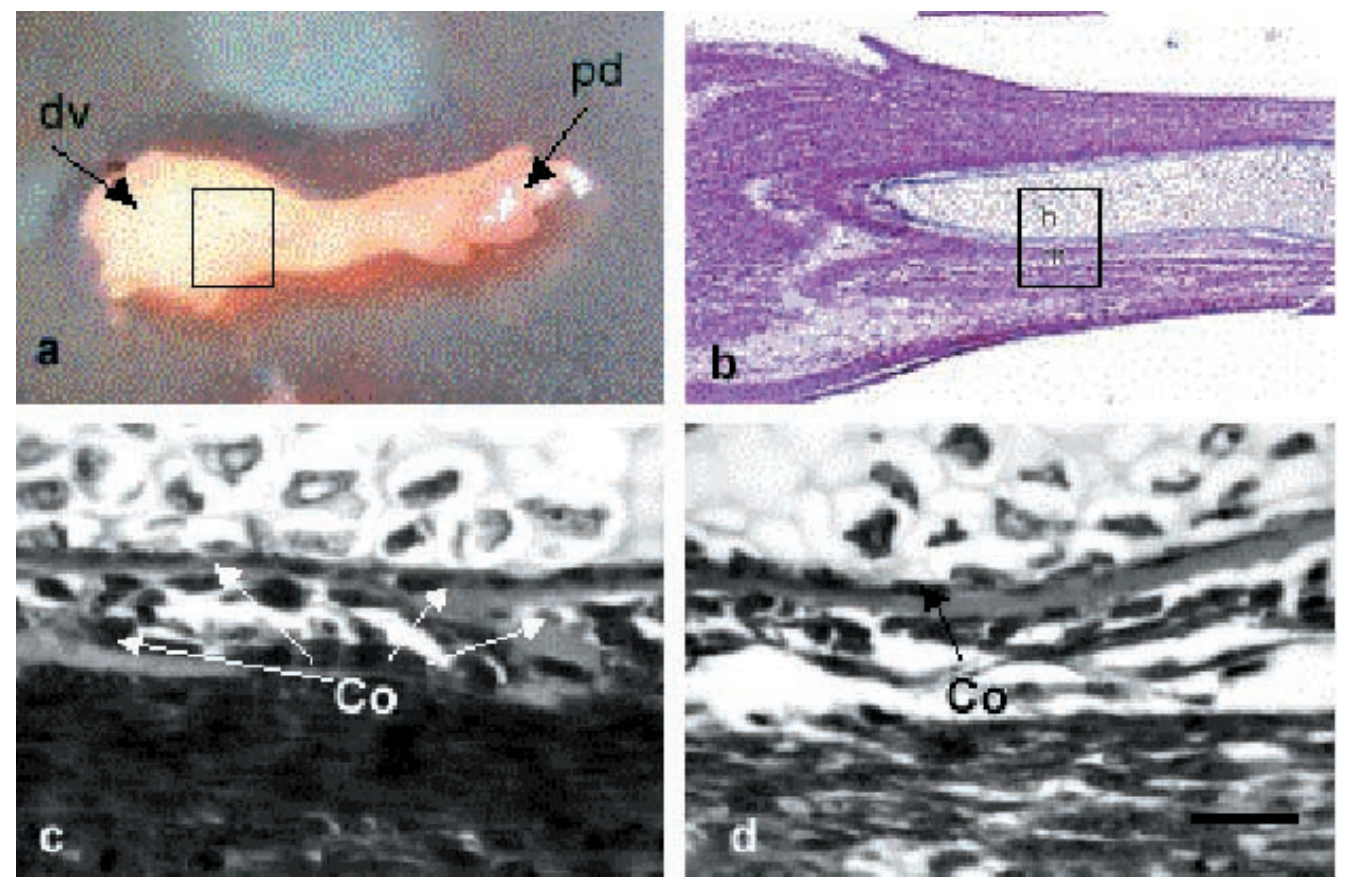

Fig.1. Chick embryo thigh dissected by dorsoventral region (Fig.1a).

Longitudinal section on thigh haematoxilyn-eosin counterstained show muscle tissue region $(\mathrm{m})$ and cartilaginous primordium constituted by hyalin cartilage. 10x (Fig.1b). High magnification (40x) on longitudinal section Gomori's trichrome stained showed loss of collagen (Co) subtrate. Control (Fig.1c) and treated (Fig.1d). Barra $=20 \mu \mathrm{m}$.

1c). In contrast with controls, the muscle tissue treated basal region, between hyaline and muscle tissue showed showed atrophy, detachment of few fibers, $57.14 \%$ decrease in the number of cells (arrow) and loss of collagen substrate (Fig. 1d).

Shigella excretion product-induced muscle tissue apoptosis The results of apoptosis tests showed that excretion products cause extensive apoptotic cells death distributed in the muscle tissue. The distributions of apoptotic cells correspond to the region showing histopathological changes observed by TUNEL assay (Figs. 2a, control y 2b, treated). The reaction of the TUNEL assay in the treated tissue was greater than in control tissue. The morphological cell changes incliding cell shirinkage associated with nuclear fragmentation (arrows). Histopathological changes are related to a significant change in the determined apoptotic index on the muscular tissue of chick embryo regarding the control. This change translates into a value of $2.27 \%$ of apoptotic index for the treated group in comparison to $0.5 \%$ of apoptotic index for the control (Fig. 2c). Greater intensity of the reaction in the Shigella dysenteriae excretion product treated muscle is emphasized. Quantitative analysis showed that mitotic index percentage decreased in $0.62 \%$ with regard to control in response to treatment. The changes of the mitotic index were not significant (Fig. 2d).

In vitro. Cultured myoblasts showed a fusion event between several mononuclear myoblasts formed. These cells align together and fuse to form the multinuclear myotubes, characteristic of muscle tissue. The sign of apoptosis determined ex vivo through the TUNEL reaction translates in vitro with the appearance of morphologic signals characteristic of this process of cellular death during the myogenesis (Fig. 3 ). The degree of cells assembly is emphasized by its gathering to form the fiber in control culture (Figs 3. a, b, c, d). The presence of membrane blebbing (arrows), vacuoles of diverse sizes (double arrows), and loss of cell adhesion were evident in the representation from the myogenesis in vitro under the treatment with the culture filtrate of Shigella dysenteriae (Figs. 3 a', b', c' and d'). The assembly process, in terms of the number of incorporated cells, is reduced in $50 \%$.

\section{DISCUSSION}

The cell injury involving cell death by apoptosis, which is an active process generally characterized by morphological cell changes including cell shrinkage associated with cytoplasmic condensation, vacuolation, membrane blebbing and loss of cell adhesion (Zimmermann et al., 2001). It is worth noting that we observed culture filter of Shigella dysenteriae induced apoptosis in the present study. The TUNEL assays performed revealed a massive apoptotic effect induced by the excretion products. It has been demonstrated that Shiga toxin induces apoptosis (Sandvig, 2001) The phenomenon of apoptosis begins with striking changes in both the cytoplasm and the nucleus. The cytoplasm undergoes marked blebbing at the periphery of cells, undoubtedly due to mediated changes in cytoskeletal-membrane interaction. During the progression of the injuries the cytoplasmic blebs become 

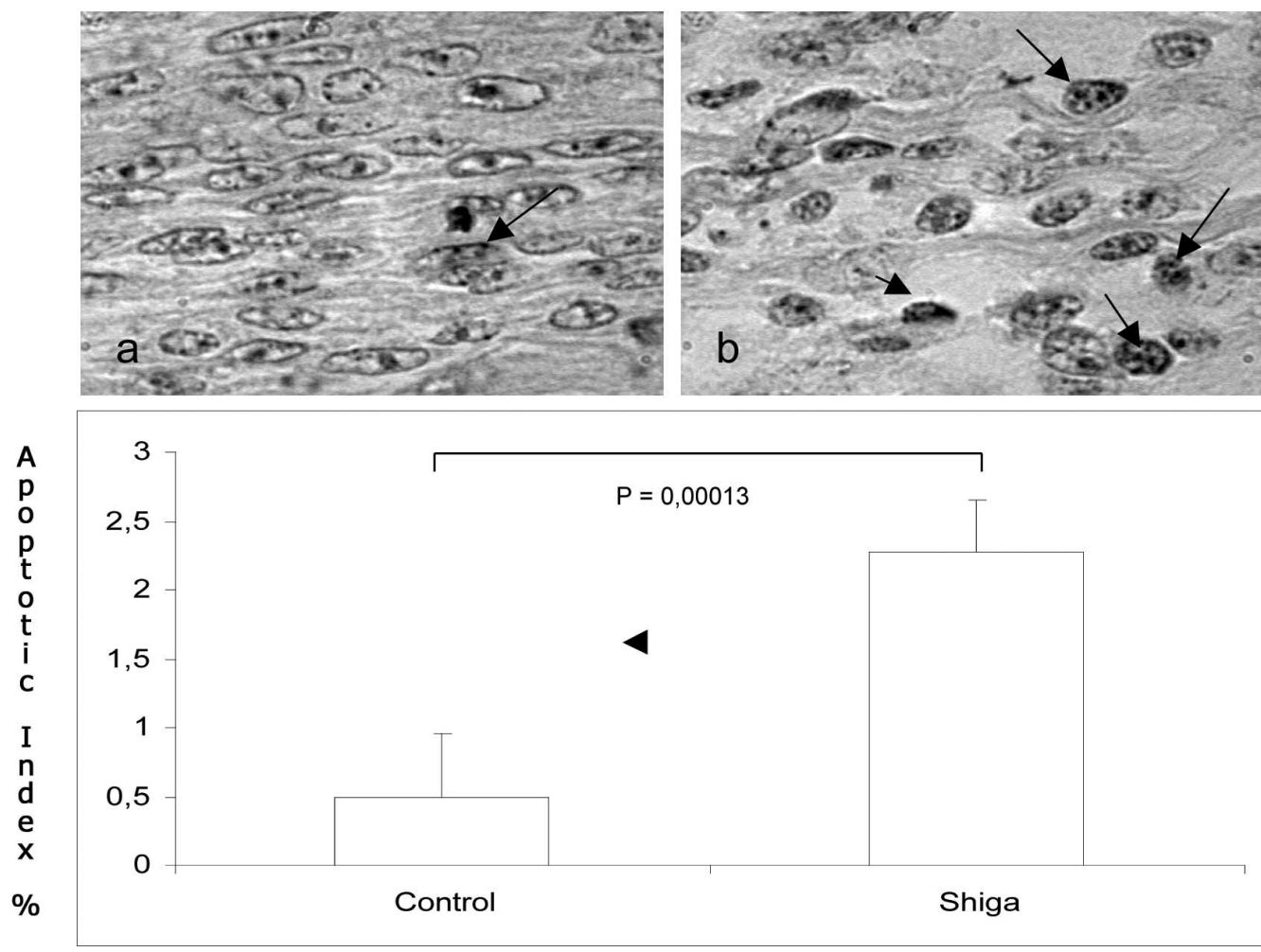

Fig. 2. TUNEL-positive nuclei in muscle tissue. Control (Fig.2a) and treated (Fig.2b). Arrows indicate positive nuclei. Histogram (Fig.2c) showing per cent apoptotic index quantified by counting TUNEL-positive nuclei in the light microscope at 40x magnification. TUNEL-positive nuclei were expressed as percentage of total. Values

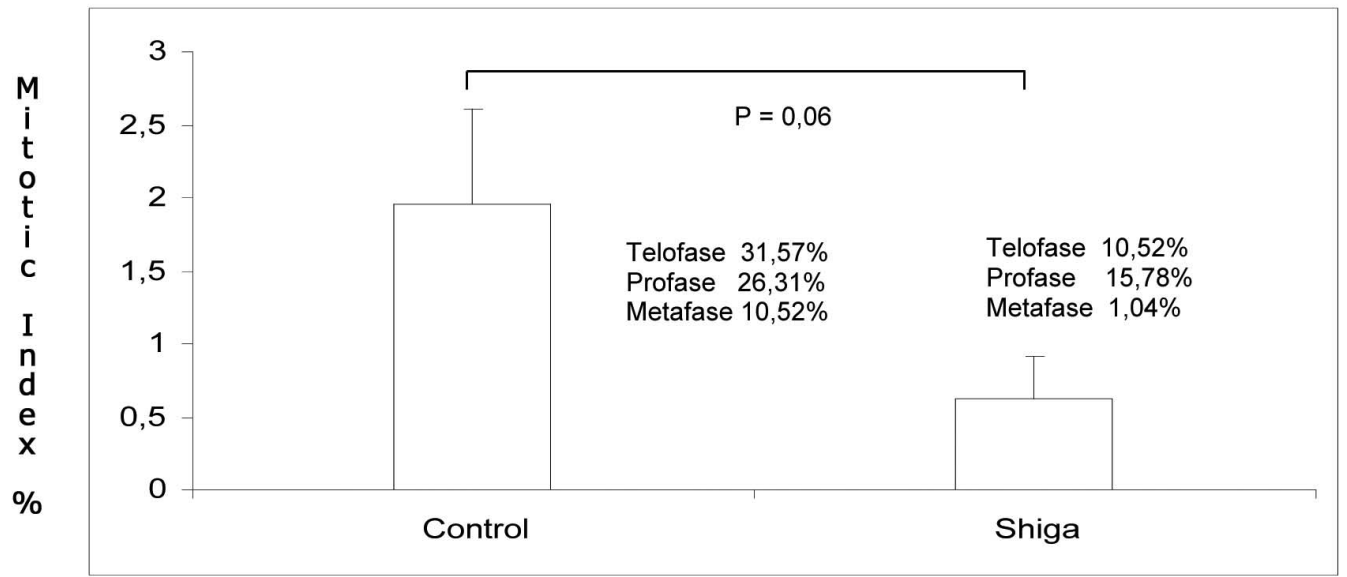
are means \pm SD. $\mathrm{p}=$ 0,00013 . Mitotic index per cent.

(Fig.2d) not showed significant difference.

more numerous and ultimately, a marked increase of the plasmatic membrane permeability occurs, thus permitting the escape of cytosolic enzymes and finally leading to cell death. These membrane effects appear to be direct result of activation of calcium-dependent phospholipases and proteases (Trump \& Berezesky, 1992). It can be speculated that this pathway would significantly contribute to muscle cell death induced by culture filtrate of Shigella dysenteriae in the present study, although it needs experimental data to be proved. Although we did not perform direct measurements of proteolytic activity; perform direct measurements of loss of cell coupling between collagen matrix and muscle fibers; and loss of cell to cell communication; it appears that the presented results are the consequence of the activation of protease-like collagenase. This knowledge allows analysis of the bases of cell injury caused by culture filtrate of Shigella dysenteriae. Hence, numerous studies have examined the mechanism of cell death mediated by purified Stx's. Many cell types have been used. In this way, culture cells or cell lines were used in these studies including epithelial cells, endothelial cells, astrocytomic cells, monocytic and amniotic cell lines. Shiga toxin induces, cell lysis characteristic of programmed cell death or apoptosis (Joens et al., 2000; Susiki et al., 2000), DNA degradation and release of the cellular content. This process can thereby facilitate proteolytic attack on neighboring cells and contributes to the toxic effect in 

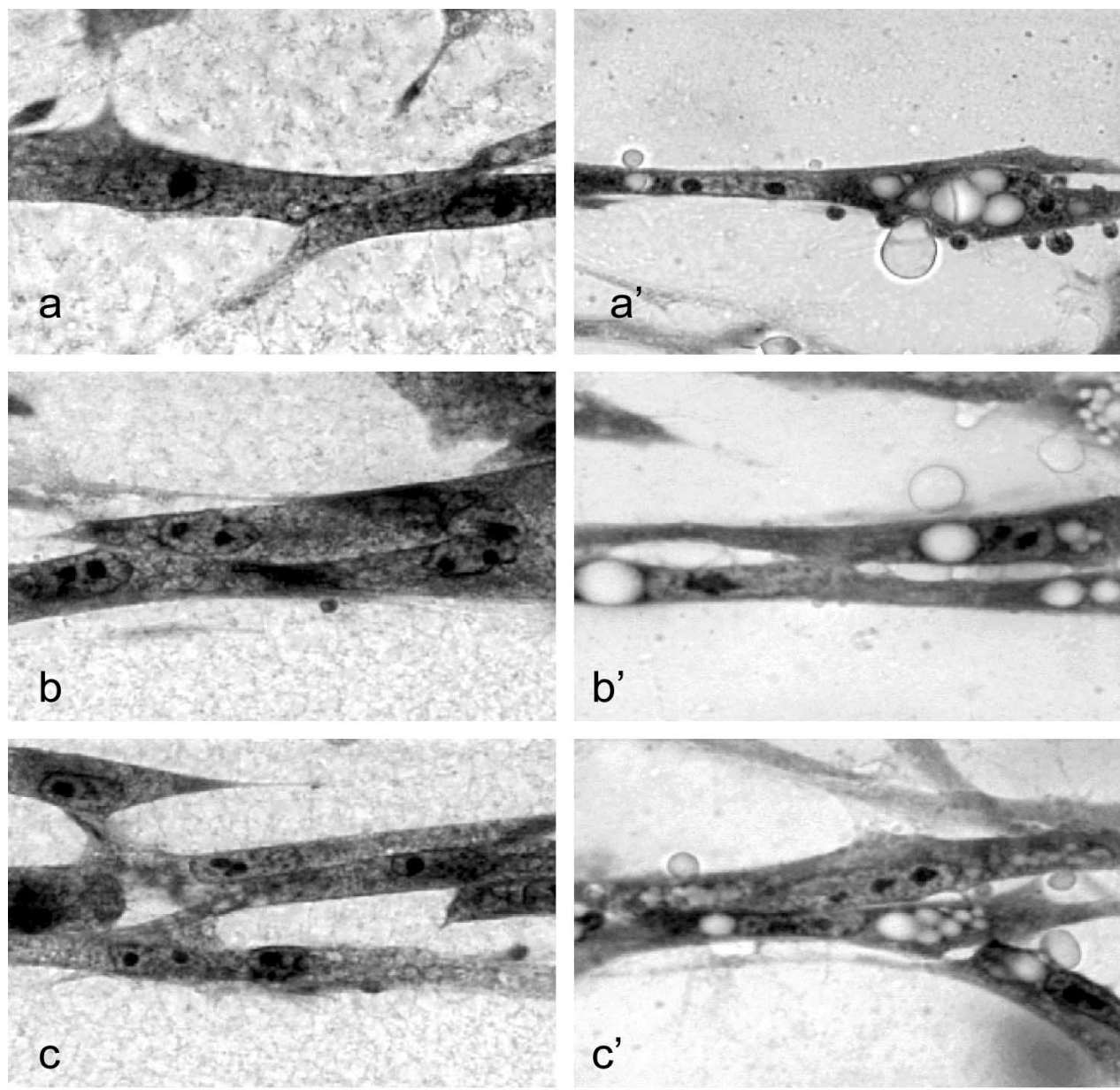

Fig. 3. Myogeneis in vitro. Control (Fig.3 a, b, c, d) and treated (Fig a', b', c', d' ). Hanging-drop culture myoblasts tolouidine blue stained 100x. These cells showed shrinkage associated with c y t o p l a s m i c condensation, vacuolation (double arrows) and membrane blebbing (sin-
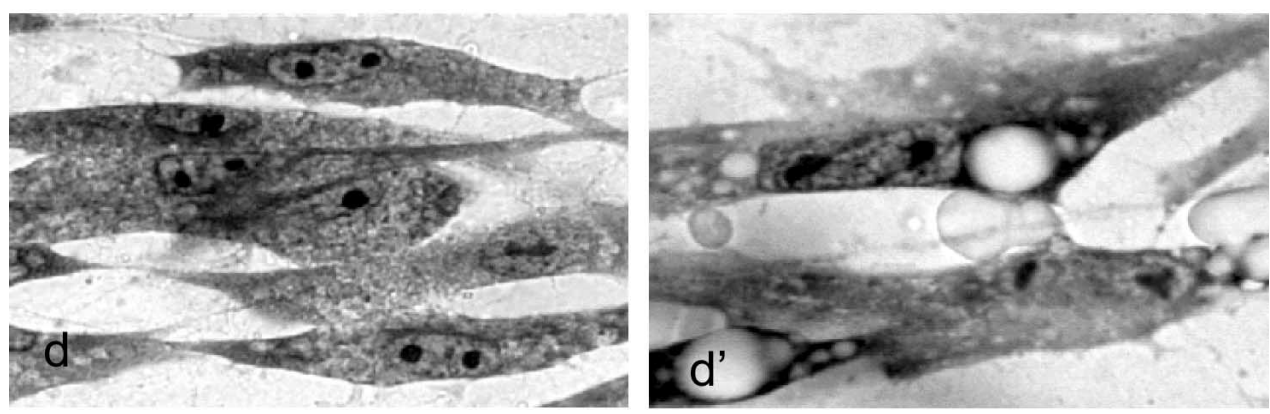
gle arrow). Barra $=6 \mu \mathrm{m}$.

the whole organism. Recently, a mechanism of signaling for programmed cell death was described which requires the activation of caspase 12. In mice, caspase 12 appears to be localized to endoplasmic reticulum (ER), and is activated in response to stimuli by which ER became stressed and release the calcium stored (Nakagawa et al., 2000). On the other hand, changes in cell junction include increases of intracellular calcium. Calcium increase results in a decrease of cell-cell communications and could result in detachment of desmosomes, intermediate junctions and tight junctions. Likewise, it has been proposed that calcium showed signs of acute cells injury with evident vacuolation, membrane blebbing and loss of cell adhesion (Orrenius et al., 1989).
As is generally recognized, mitochondrial cytochrome-c release is followed by the formation of cytochrome-c and dATP-dependent apoptotic protease activating factor (Apaf1)/caspase-9 complex, and, eventually, activation of caspase -3 (Tafani et al., 2000) The real molecular mechanisms are not known, however, in future study on the relationship between collagen and Shiga toxin apoptotic cell death could lead to a better understanding of this problem.

ACKNOWLEDGEMENTS. Thanks to Dr. José Ercolino for the aid in the review of the manuscript. 
AlVÁREZ, M., URbiNA, G.; MÜLLER, C. \& PERDOMO. L. Producto de excreción de Shigella dysenteriae y la muerte celular por apoptosis en tejido muscular de embrión de pollo. Int. J. Morphol., 25(3):615-620, 2007.

RESUMEN: El objetivo del presente trabajo ha sido evaluar el daño celular agudo generado por el producto de excreción de Shigella dysenteriae sobre el tejido muscular del miembro inferior de embrión de pollo, así como sobre los mioblastos obtenidos a partir del cultivo de explantes de tejido muscular desarrollado en gota pendiente. Tres controles fueron definidos: a) solución de tiroide b) caldo de infusión cerebro-corazón (CCC), c) producto de excreción bacteriano no toxigénico de E. coli O157:H7. El producto de excreción fue obtenido a partir de la centrifugación y filtrado del medio de cultivo de Shigella dysenteriae con 24 horas de crecimiento. Luego de una hora de tratamiento, los cambios morfológicos del tejido muscular fueron evaluados a través del examen histopatológico, con técnicas de análisis de imágenes sobre cortes teñidos con hematoxilina-eosina (H\&E) y Tricrómico de Gomori. El ensayo enzimático TUNEL fue utilizado para evaluar el índice de apoptosis. Señales morfológicas de muerte celular fueron evaluadas en mioblastos en cultivo En contraste con los controles, el tejido muscular presentó signos de atrofia, con fibras desconectadas y pérdida del $57,14 \%$ del número total de células así como pérdida de la matriz de colágeno. Un incremento en el índice apoptótico y una reducción de índice mitótico fueron registrados. Esto último fue no significativo. Los mioblastos en cultivo presentaron signos morfológicos de apoptosis tales como protuberancias en la membrana, vacuolización, agregación de cromatina alrededor del núcleo y pérdida de la adhesión celular. Se concluye que el producto de excreción afecta al tejido muscular esquelético del miembro inferior de embrión de pollo e induce lesiones de toxicidad relacionadas con la muerte celular por apoptosis.

PALABRAS CLAVE: Shigella dysenteriae; Toxina Shiga; Embrión de pollo; Tejido muscular; Apoptosis.

\section{REFERENCES}

Cherla, P. R.; Sang-Yun, L. \& Vernon L.T. Shiga toxins and apoptosis. FEMS Microbilogy Letters., 159-1661, 2003.

Hamburger, V. \& Hamilton, H. L. A series of normal stages in development of the chick embryo. Dev. Dyn., 195(4):231-72, 1992.

Hartung, T.; Balls, M.; Bardouille, C.; Blanck, O.; Coecke S.; Gstraunthaler, G. \& Lewis D. Good cell culture practice. ATLA, 30:407-14, 2002.

Joens, N. L.; Islur, A.; Haq, R.; Mascarenhas, M. M.; Karmali, M. A.; Perdue, M. H.; Zanke, B. W. \& Sherman, P. M. Escherichia coli shiga toxins induce apoptosis in epithelial cells that is regulated by Bcl-2 family. Am. J. Physiol., 278:G811-G89, 2000 .

Meyers, K. E. C. \& Kaplan B. S. Many cell types are shiga toxin targets. Kidney Int., 57:2650-1, 2000.

Nakagawa, T.; Zhu, H.; Morishima, N.; Li, E.; Xu, J.; Yankner B. A. \& Yuan J. Caspase 12medaites endoplasmic reticulumspecific apoptosis and cytotoxicity by amyloid-b. Nature, 403:98-103, 2000.

O’Loughlin, E. \& Robins-Browneb, M. R. Effect of Shiga toxin and Shiga-like toxins on eukaryotic cells. Microbes and Infect., 3(6):493-507, 2001.

Orrenius, S.; Mc ConKey, D. J.; Bellomo, G. \& Nicotera, P. Role of $\mathrm{Ca}^{+2}$ in toxic cell killing. Trends Pharmacol Sci., 10:281-5, 1989.

Paton, J. C. \& Paton, A.W. Pathogenesis and diagnosis of Shiga toxin-producing Escherichia coli infections. Clin. Microbiol. Rev., 51:450-79, 1998.
Rojo, M. G.; García, B. G.; García, G. G. \& Vicente, M.C. Digital slides in pathology departments (I). A review of basic aspects in digital imaging. Rev. Esp. Patol., 38(2):69-77, 2005.

Sandvig, K. Shiga Toxin. Toxicon., 39:1629-35, 2001.

Schmitt, C. K. \& Meysick, K. C. Bacterial toxins: friends or foes? Emerg. Infect. Dis., 5:222-34, 1999.

Sterm, C. D. The chick: agreat model system becomes even greater. Developmental Cell., 8:9-17, 2005.

Susiki, A.; Doi, H.; Matsuzawa, F.; Aikawa, S.; Takiguchi, K.; Kawano, H.; Hayashida, M. \& Ohno, S. Bcl-2 antiapoptotic protein mediates verotoxin II- induced cell death: possible association between $\mathrm{Bcl}-2$ and tissue failure by coli $\mathrm{O} 157: \mathrm{H} 7$. Genes. Dev., 14:1734-40, 2000.

Tafani, M.; Schneider, T. G.; Pastorino, J. G. \& Farber, J. L. Cytochrome c- dependent activation of caspase- 3 by tumor necrosis factor requires induction of mitochondrial permeability transsition. Am. J. Pathol., 156:2111-121, 2000.

Trump, F. B. \& Berezesky, K. I. Cellular and molecular basic of toxic cell in injury. In Cardiovascular Toxicology. $6^{\text {th }}$ Ed. Edit.: Daniel Acosta Jr and Horning-Raven Press, New York, 1992.

Zimmermann, K. C.; Bonzon, C. \& Green, D.R. The mechenery of programmed cell death. Pharmacol Ther., 92: 57-70, 2001.

Correpondence to:

Dr. Marco Alvarez

Instituto Anatómico "José Izquierdo",

Facultad de Medicina

Universidad Central de Venezuela

VENEZUELA

Email: alvarezm@ucv.ve.

Received: 20-06-2007 alvarezmenator@gmail.com Accepted: 22-07-2007 